\title{
PEMBERDAYAAN MASYARAKAT MELALUI PROGRAM PEMBANGUNAN INFRASTRUKTUR PERDESAAN DALAM MENINGKATKAN KESEJAHTERAAN MASYARAKAT KECAMATAN WANASALAM KABUPATEN LEBAK
}

Oleh :

Ahmad Sururi

Dosen Ilmu Administrasi Negara Fakultas Ilmu Sosial dan Ilmu Politik

Universitas Serang Raya

\begin{abstract}
This study aims to describe and analyze the empowerment of communities through the Rural Infrastructure Development Program (PPIP) in Improving Public Welfare Wanasalam District of Lebak

From the results of this study concluded that the Community Empowerment through Rural Infrastructure Development (PPIP) in improving public welfare Wanasalam District of Lebak has implemented 10 (ten) of the 12 (twelve) principles proposed community empowerment in Mardikanto Dahatma and Bhatnagar (2013: 106), then through the Community Empowerment for Rural Infrastructure Development (PPIP) in improving public welfare Wanasalam District of Lebak not carry two (2) principles of community empowerment which principles of community development cooperation is based on the analysis of the participation and empowerment of the principle of democratic society based on the analysis in the application science, this is due 1.Less public's understanding of the meaning of community empowerment and the existence of the Rural Infrastructure Development Program (PPIP), 2 Lack of socialization given by the community facilitators and institutional devices village in providing information on the activities and the lack of public awareness both as individuals and members of society concerning the conditions and environment, 3 There is a culture of compliance citizens against warlords (formal and informal leaders) that affect people's attitudes in policy decision making.
\end{abstract}

Keyword: Community Empowerment, Rural Infrastructure Development Program (PPIP), Public Welfare.

\section{A. PENDAHULUAN}

Bahwa tidak ada satupun pemerintahan dari suatu negara dengan wilayah yang sangat luas dapat menentukan kebijakan secara efektif ataupun dapat melaksanakan kebijakan dan progamprogramnya secara efisien melalui sistem sentralisasikarena itu urgensi pelimpahan kebutuhan atau penyerahan sebagian kewenangan pemerintah pusat, baik dalam konteks politik maupun secara administratif kepada organisasi atau unit di luar pemerintah pusat yang dalam hal ini adalah pemerintahan daerah menjadi hal yang sangat penting untuk dilakukan guna

menggerakkan dinamika sebuah pemerintahan.

Untuk melaksanakan pembangunan daerah secara tepat, efektif dan efisien, dibutuhkan kredibilitas sumber daya manusia masyarakat dan kualitas aparatur pemerintahan yang mampu merumuskan dan memformulasikan kebijakan, di sini dibutuhkan adanya kebijakan-kebijakan dari sumber daya manusia pemerintah daerah yang mampu merespon persoalan masyarakat setempat karena pada hakekatnya pembangunan daerah merupakan tugas yang terbebankan kepada seluruh masyarakat di daerah dan pembangunan suatu daerah tidak hanya dimonopoli oleh aktor-aktor kebijakan eksekutif (pemerintahan provinsi, pemerintah kabupaten dan kota)dan legislatif (anggota Dewan Perwakilan Rakyat Daerah) saja, melainkan terdapat 
peranan dari seluruh masyarakat untuk merencanakan, mengarahkan, menentukan dan mengawasi proses pelaksanaan pembangunan daerah itu sendiri.

Sebagai sebuah konsep penyelenggaraan pemerintahan, desentralisasi pada akhirnya menjadi pilihan akibat ketidakmungkinan sebuah negara yang wilayahnya luas dan penduduknya banyak untuk mengelola manajemen pemerintah secara sentralistis.Desentralisasi dalam hal ini menjadi sebuah pilihan karena di dalamnya terkandung semangat demokrasi untuk mendekatkan partisipasi masyarakat dalam menjalankan sebuah pembangunan.Pada perkembangan selanjutnya, desentralisasi menjadi semangat bagi negara-negara yang menyepakati demokrasi sebagai landasan gerak utamanya.Kesamaan orientasi desentralisasi dan demokratisasi inilah yang membuat sebuah pemerintahan di masa kini tidak bisa lagi memerintah secara sentralistik dan pada akhirnya terdapat kesadaran baru di kalangan para penyelenggara pemerintahan bahwa masyarakat merupakan pilar utama yang harus dilibatkan dalam berbagai formulasi dan implementasikebijakan pembangunan.

Di Indonesia, keberadaan UU No 5 Tahun 1974 tentang Pemerintahan Daerah sebagai payung hukum merupakan sumber sentralisasi kebijakan pembangunan maka dengan datangnya reformasi pemerintahan yang melahirkan UU No 22 Tahun 1999 dan UU No 25 Tahun 1999, dan direvisi melalui UU No 32 Tahun 2004 dan UU No 23 Tahun 2014 tentang Pemerintahan Daerah lebih membuka peluang partisipasi masyarakatdan upaya pemberdayaan pembangunan berbasis masyarakat dalam rangka merumuskan dan melakasanakan kebijakan pembangunan. Pembangunan berbasis masyarakat secara sederhana dapat diartikan sebagai pembangunan yang mengacu kepada kebutuhan masyarakat, direncanakan dan dilaksanakan oleh masyarakat dengan sebesar-besarnya memanfaatkan potensi sumber daya yang ada dan dapat diakses oleh masyarakat.

Pembangunan dari atas (top down) menempatkan pemerintah pusat dan atau elit masyarakat sebagai pencetus gagasan dengan asumsi mereka tahu yang terbaik bagi masyarakatnya, tanpa harus

mendengarkan akomodasi aspirasi masyarakat (bawah) dilibatkan atau dimobilisasi dengan memberikan insentif dan atau menumbuhkan rasa takut. Sebaliknya pembangunan dari bawah (bottom up) memberikan kesempatan kepada masyarakat untuk berinisiatif sejak perencanaan dengan asumsi bahwa masyarakat memiliki kemampuan untuk mengidentifikasi masalah dan kebutuhan serta cara-cara terbaik yang cocok dengan kondisi mereka.

Pemberdayaan masyarakat sebagai sebuah strategi sekarang telah banyak diterima bahkan telah berkembang dalam berbagai literatur di dunia barat. Pemberdayaan masyarakat sebagai sebuah konsep pembangunan merangkum nilai-nilai sosial dan budaya yang berkembangan dinamis di masyarakat dan mencerminkan paradigma pembangunan yang bersifat people centered atau berpusat kepada masyarakat sebagai subjek dan pelaku

pembangunan. Secara konseptual pemberdayaan masyarakat sebagai upaya meningkatkan harkat dan martabat lapisan masyarakat yang dalam kondisi sekarang tidak mampu untuk melepaskan diri dari

perangkap kemiskinan dan keterbelakangan. Dengan kata lain memberdayakan adalah memampukan dan memandirikan masyarakat.

Program pembangunan infrastruktur perdesaan atau yang lebih dikenal sebagai PPIP adalah salah satu program pemerintah dari Kementerian Pekerjaan Umum melalui Direktorat Jendral Cipta Karya yang berupaya menciptakan dan meningkatkan kualitas kehidupan masyarakat, baik secara individu maupun kelompok melalui partisipasi dalam memecahkan berbagai permasalahan yang terkait kemiskinan dan ketertinggalan desanya sebagai upaya meningkatkan kualitas kehidupan, kemandirian dan kesejahteraan masyarakat. PPIP merupakan program bantuan langsung masyarakat yang bantuannya meliputi 
fasilitasi dan memobilisasi masyarakat dalam melakukan identifikasi permasalahan kemiskinan, menyusun perencanaan dan melaksanakan pembangunan infrastruktur desanya.

Dalam pelaksanaannya, PPIP meningkatkan kualitas pemberdayaan masyarakat dan peran stakeholder dalam pelaksanaan program.Menurut Buku Pedoman Pelaksanaan PPIP yang diterbitkan oleh Direktorat Jendral Cipta Karya Kementerian Pekerjaan Umum halhal tersebut dilakukan melalui :

1. Peningkatan kepekaan dan kesadaran di semua tingkatan melalui pelaksanaan Public Awareness Campaign (PAC) yang optimal

2. Peningkatan kapasitas penyelenggara melalui pelatihan yang akan diintegrasikan ke dalam sistem penyelenggaraan program

3. Pemantauan kinerja yang akan dilakukan secara berjenjang dari tingkat pusat, provinsi, kabupaten, sampai ke tingkat terendah di desa

4. Peningkatan partisipasi masyarakat secara aktif dalam pelaksanaan program khususnya peran serta perempuan dan masyarakat kelompok miskin, terutama dalam proses pengambilan keputusan

5. Penilaian kinerja yang dikaitkan dengan sistem, penghargaan, dan sanksi bagi penyelenggara program, dari tingkat provinsi, kabupaten, sampai tingkat desa berdasarkan kinerja dalam pelaksanaan program; dan

6. Penguatan mekanisme serta

implementasi penanganan pengaduan

Selanjutnya Program Pembangunan

Infrastruktur Pedesaan (PPIP) berfokus pada : 1).peningkatan akses masyarakat terhadap pelayanan infrastruktur dasar permukiman perdesaan, 2).peningkatan kapasitas perencanaan dan pengembangan masyarakat serta 3).peningkatan kapasitas pemangku kepentingan (stakeholders) dalam penyelenggaraan pembangunan dengan penerapan tata kelola pemerintahan yang baik (good governance). PPIP 2014 merupakan bagian dari Program Nasional Pemberdayaan Mandiri (PNPM) yang tersebar di 32 (tiga puluh dua) propinsi dengan sasaran lokasi mengacu kepada Surat Keputusan (SK) Menteri Pekerjaan Umum. Salah satu daerah yang mendapat program ini adalah Kecamatan Wanasalam Kabupaten Lebak Provinsi Banten yang tersebar di 3 (tiga) desa yaitu Desa Cisarap, Desa Cilangkap dan Desa Parungsari.

Sebagai program yang berbasis pemberdayaan masyarakat, PPIP senantiasa mendorong keterlibatan masyarakat secara optimal dalam semua tahapan kegiatan, mulai dari pengorganisasian masyarakat, penyusunan rencana program, menentukan kegiatan pembangunan infrastruktur perdesaan, serta pengelolaanya. Disamping itu terdapat 3 (tiga) komponen PPIP sebagai landasan pemberdayaan masyarakat yaitu 1). Penguatan kapasitas perencanaan masyarakat, 2). Peningkatan layanan dan penyediaan infrastruktur desa melalui Bantuan Langsung Masyarakat (BLM) dan 3).Peningkatan kapasitas pelaksanaan dan pengendalian program.

Rendahnya tingkat pemberdayaan masyarakat diindikasikan dengan kurangnya tingkat kerjasama dan partisipasi masyarakat dalam tahap penyiapan dan mobilisasi masyarakat dimana tingkat kehadiran masyarakat terutama kaum miskin dan perempuan pada sosialisasi desa dan musyawarah desa 1 masih sangat rendah, rendahnya tingkat pemberdayaan masyarakat pada tahap perencanaan partisipatif oleh masyarakat diindikasikan kurangnya tingkat kehadiran masyarakat pada kegiatan musyawarah desa II

sedangkan rendahnya tingkat pemberdayaan masyarakat pada tahap pelaksanaan fisik ditemukan bahwa pada pelaksanaan pembangunan infrastruktur dikontraktualkan atau menggunakan pihak ke-3 dan tidak dilaksanakan secara swakelola atau oleh masyarakat langsung untuk memberikan tambahan pendapatan kepada masyarakat setempat.

Berdasarkan latar belakang permasalahan yang ada, dapat dirumuskan permasalahan sebagai berikut :

1. Rendahnya tingkat pemberdayaan 
masyarakat dalam kerjasama dan partisipasi pelaksanaan kegiatan, hal ini berdasarkan data tingkat kehadiran masyarakat dalam tahap penyiapan dan mobilisasi dan tahap perencanaan partisipatif yang rendah.

2. Rendahnya tingkat pemberdayaan masyarakatdalamdemokrasi

(metodepemberdayaan) dan pengambilan keputusan, hal ini berdasarkan temuan bahwa dalam kegiatan musyawarah desa masyarakat cenderung bersikap pasif dan menerima saja hasil keputusan.

\section{B. TINJAUAN PUSTAKA}

1. Pemberdayaan Masyarakat

Konsep pemberdayaan masyarakat mencakup pengertian "pembangunan masyarakat (community development) dan pembangunan yang bertumpu pada masyarakat (community-based development) Chamber tahun 1995" (Kartasasmita, 1997:41). Pendekatan utama dalam konsep pemberdayaan adalah bahwa masyarakat tidak dijadikan obyek dari berbagai proyek pembangunan, tetapi

merupakan subyek dari upaya pembangunannya sendiri.

$$
\text { Pembangunan partisipatif }
$$

mempunyai kaitan yang erat dengan pemberdayaanmasyarakat, dimana pada pembangunan partisipatif diperlukan upaya dan langkah-langkah untuk mempersiapkan masyarakat guna memperkuat kelembagaan masyarakat agar mereka mampu mewujudkan kemajuan, kemandirian, dan kesejahteraan dalam suasana keadilan yang berkelanjutan untuk meningkatkan harkat dan martabatnya serta mampu melepaskan diri dari perangkap kemiskinan dan

keterbelakangan. Upaya tersebut merupakan salah satu wujud nyata dari pemberdayaan masyarakat (Sumaryadi, 2005:111).

"Empowerment - "process by which individuals and groups gain power, acces to resources and control over their own lives. In doing so, they gain the ability to achieve their highest personal and collectives apirations and goals" (Robbins,
Chatterjee \& Canda, 1998 dalam Aprillia theresia dkk, 2014:115)

Sedangkan

Mardikanto

(2013:100) mendefinisikan pengertian pemberdayaan masyarakat adalah :

"Proses perubahan sosial, ekonomi dan politik untuk memberdayakan dan memperkuat kemampuan masyarakat melalui proses belajar bersama yang partisipatif, agar terjadi perubahan perilaku pada diri semua stakeholders (individu, kelompok dan kelembagaan) yang terlibat dalam proses pembangunan demi terwujudnya kehidupan yang semakin berdaya, mandiri dan partisipatif yang semakin sejahtera secara berkelanjutan".

Filosofi pemberdayaan masyarakat dan paling banyak dikemukakan oleh berbagai pihak dan dalam banyak kesempatan dikutip oleh Kelsey dan Hearne (1995) bahwa "falsafah pemberdayaan masyarakat harus berpijak kepada pentingnya pengembangan individu di dalam perjalanan pertumbuhan masyarakat dan bangsanya Mardikanto dan Soebiato, 2013. Pemberdayaan masyarakat pada dasarnya merupakan proses untuk membuat masyarakat menjadi berdaya. Setiap anggota masyarakat dalam sebuah komunitas sebenarnya memiliki potensi, gagasan serta kemampuan untuk membawa dirinya dan komunitasnya untuk menuju ke arah yang lebih baik, namun potensi itu terkadang tidak bisa berkembang disebabkan faktorfaktor tertentu.

Pemberdayaan masyarakat adalah sebuah konsep pembangunan ekonomi yang merangkum nilai-nilai sosial. Konsep ini mencerminkan paradigma baru pembangunan, yakni yang bersifat "peoplecentered, participatory, empowering, and sustainable" (Chambers, 1995). Konsep ini lebih luas dari hanya semata-mata memenuhi kebutuhan dasar (basic needs) atau menyediakan mekanisme untuk mencegah proses pemiskinan lebih lanjut (safety net), yang pemikirannya belakangan ini banyak dikembangkan sebagai upaya mencari alternatif terhadap konsep-konsep pertumbuhan di masa yang lalu. Konsep ini 
berkembang dari upaya banyak ahli dan praktisi untuk mencari apa yang antara lain oleh Friedman (1992) disebut alternative development, yang menghendaki "inclusive democracy, appropriate economic growth, gender equality and intergenerational equity".

Dengan demikian, pemberdayaan adalah sebuah proses dan tujuan. Sebagai proses, pemberdayaan adalah serangkaian kegiatan untuk memperkuat kekuasaan atau keberdayaan kelompok lemah dalam masyarakat, termasuk individu-individu yang mengalami masalah kemiskinan. Sebagai tujuan, maka pemberdayaan menunjuk pada keadaan atau hasil yang ingin dicapai oleh sebuah perubahan sosial yaitu masyarakat yang berdaya, memiliki kekuasaan atau mengetahui pengetahuan dan kemampuan dalam memenuhi kebutuhan hidupnya baik yang bersifat fisik, ekonomi maupun sosial seperti memiliki kepercayaan diri, mampu menyampaikan aspirasi, mempunyai mata pencaharian, berpartisipasi dalam kegiatan sosial dan mandiri sebagai tujuan seringkali digunakan sebagai indikator keberhasilan pemberdayaan sebagai sebuah proses.

Menurut Sumodiningrat

(1999)

pemberdayaan masyarakat memerlukan kepedulian yang diwujudkan dalam kemitraan dan kebersamaan pihak yang sudah maju dengan pihak yang belum berkembang. Dalam hal ini pemberdayaan merupakan suatu proses perubahan ketergantungan menjadi kemandirian. Sumodiningrat (1999) juga menjelaskan bahwa segenap program pemberdayaan masyarakat yang dirancang untuk menanggulangi ketertinggalan merupakan bagian dari upaya mempercepat proses perubahan kondisi sosial-ekonomi masyarakat yang masih tertinggal.

Pemberdayaan adalah sebuah proses agar setiap orang menjadi cukup kuat dalam berpartisipasi dalam berbagi pengontrolan dan mempengaruhi kejadian-kejadian serta lembaga-lembaga yang

mempengaruhi kehidupannya. Pemberdayaan menekankan bahwa orang memperoleh keterampilan, pengetahuan, dan kekuasaan yang cukup untuk mempengaruhi kehidupannya dan kehidupan orang lain yang menjadi perhatiannya (Parsons et al. 1994 dalam Mardikanto 2010). Upaya memberdayakan masyarakat adalah upaya untuk menumbuhkan potensi yang terpendam dalam masyarakat yang mengharuskan adanya fasilitator untuk membangun kapasitas produktif masyarakat (Indrianingrum 2011).

Sedangkan dasar-dasar pemberdayaan masyarakat adalah: mengembangkan masyarakat khususnya kaum miskin, kaum lemah dan kelompok terpinggirkan, menciptakan hubungan kerjasama antara

masyarakat dan lembaga-lembaga pengembangan, memobilisasi dan optimalisasi penggunaan sumber daya secara keberlanjutan, mengurangi ketergantungan, membagi kekuasaan dan tanggung jawab, dan meningkatkan tingkat keberlanjutan. (Delivery dalam Sutrisno, 2005:17).

Lebih lanjut, Dahama dan Bhatnagar dalam Mardikanto (2010) mengungkapkan prisip-prinsip pemberdayaan yang lain yang mencakup:

1) Minat dan kebutuhan, artinya pemberdayaan akan efektif jika selalu mengacu pada minat dan kebutuhan masyarakat.

2) Organisasi masyarakat bawah, artinya pemberdayaan akan efektif jika mampu melibatkan/menyentuh organisasi masyarakat bawah, sejak dari setiap keluarga/kekerabatan.

3) Keragaman budaya, artinya pemberdayaan harus memperhatikan adanya keragaman budaya. Perencanaan pemberdayaan harus selalu disesuaikan dengan budaya lokal yang beragam.

4) Perubahan budaya, artinya setiap kegiatan pemberdayaan akan mengakibatkan perubahan budaya.

Kegiatan pemberdayaan harus dilaksanakan dengan bijak dan hatihati agar perubahan yang terjadi tidak menimbulkan kejutan-kejutan budaya.

5) Kerjasama dan partisipasi, artinya pemberdayaan hanya akan efektif jika 
mampu menggerakan partisipasi masyarakat untuk selalu bekerjasama dalam melaksanakan program-program pemberdayaan yang telah dirancang.

6) Demokrasi dan penerapan ilmu, artinya dalam pemberdayaan harus selalu memberikan kesempatan kepada masyarakatnya untuk menawar setiap ilmu alternatif yang ingin diterapkan. Yang dimaksud demokrasi disini, bukan terbatas pada tawar menawar tentang ilmu alternatif saja, tetapi juga dalam penggunaan metoda pemberdayaan, serta proses pengambilan keputusan yang akan dilakukan masyarakat sasarannya.

7) Belajar sambil bekerja, artinya kegiatan pemberdayaan harus diupayakan agar masyarakat dapat "belajar sambil bekerja" atau belajar dari pengalaman tentang segala sesuatu yang ia kerjakan. Dengan kata lain, pemberdayaan tidak hanya sekedar menyampaikan informasi atau konsep-konsep teoritis tetapi harus memberikan kesempatan kepada masyarakat sasaran untuk mencoba atau memperoleh pengalaman melalui kegiatan secara nyata.

8) Penggunaan metode yang sesuai, artinya pemberdayaan harus dilakukan dengan penerapan metoda yang selalu disesuaikan dengan kondisi lingkungan (lingkungan fisik, kemampuan ekonomi dan nilai sosial budaya) sasarannya.

9) Kepemimpinan, artinya penyuluh tidak melakukan kegiatan-kegiatan yang hanya bertujuan untuk kepentingan/kepuasannya sendiri, dan harus mampu mengembangkan kepemimpinan. Dalam hubungan ini, penyuluh sebaiknya mampu menumbuhkan pemimpin-pemimpin lokal atau memanfaatkan pemimpin lokal yang telah ada untuk membantu kegiatan pemberdayaan.

10) Spesialis yang terlatih, artinya penyuluh harus benar-benar pribadi yang telah memperoleh latihan khusus tentang segala sesuatu yangs esuai dengan fungsinya sebagai penyuluh. Penyuluhpenyuluh yang disiapkan untuk melakukan beragam kegiatan (meskipun masih berkaitan dengan kegiatan pertanian).

11) Segenap keluarga, artinya penyuluh harus memperhatikan keluarga sebagai satu kesatuan dari unit sosial. Dalam hal ini, terkandung pengertian-pengertian:

a) Pemberdayaanharus dapat mempengaruhi segenap anggota keluarga.

b) Setiap anggota keluarga memiliki peran atau pengaruh dalam setiap pengambilan keputusan.

c) Pemberdayaan harus mampu mengembangkan pemahaman bersama.

d) Pemberdayaanmengajarkan pengelolaan keuangan keluarga.

e) Pemberdayaanmendorong keseimbangan antara kebutuhan keluarga dan kebutuhan usaha tani.

f) Pemberdayaan harus mampu mendidik anggota keluarga yang masih muda.

g) Pemberdayaanharus mengembangkan kegiatankegiatan keluarga, baik yang menyangkut masalah sosial, ekonomi, maupun budaya.

h) Mengembangkanpelayanan keluarga terhadap masyarakatnya.

12) Kepuasan, artinya pemberdayaan harus mampu mewujudkan tercapainya kepuasan. Adanya kepuasan akan sangat menentukan keikutsertaan sasaran pada program-program pemberdayaan selanjutnya.

\section{Kesejahteraan Masyarakat Pengertian} sejahtera menurut W.J.S

Poerwadarimta adalah 'aman, sentosa, dan makmur'. Sehingga arti kesejahteraan itu meliputi kemanan, keselamatan dan kemakmuran. Dalam arti sempit, kata sosial menyangkut sector kesejahteraan sosial sebagai suatu bidang atau bagian dari pembangunan sosial atau kesejahteraan rakyat yang bertujuan untuk meningkatkan 
kualitas kehidupan manusia, terutama yang dikatagorikan sebagai kelompok yang tidak beruntung dan kelompok rentan, yaitu hal 
yang menyangkut program-program atau pelayanan-pelayanan sosial untuk mengatasi masalah-masalah sosial seperti, kemiskinana, ketelantaran, ketidakberfungsian fisik dan psikis, tuna sosial, tuna susila dan kenakalan remaja.

Kesejahteran sosial memiliki arti kepada keadaan yang baik, kebahagiaan dan kemakmuran, banyak orang yang menamainya sebagai kegiatan amal. Di Amerika serikat kesejahteraan sosial juga diartikan sebagai bantuan public yang dilakukan pemerintah bagi keluarga miskin dan anak-anak mereka. Para pakar ilmu sosial mendefinisikan kesejahteraan sosial dengan tinggi rendahnya tingkat hidup masyarakat.

Menurut Segel dan Bruzy (1998:8), "Kesejahteraan sosial adalah kondisi sejahtera dari suatu masyarakat. Kesejahteraan sosial meliputi kesehatan, keadaan ekonomi, kebahagiaan, dan kualitas hidup rakyat". Sedangkan Wilensky dan Lebeaux (1965:138) merumuskan kesejahteraan sosial sebagai sistem yang terorganisasi dari pelayanan-pelayanan dan lembaga-lembaga sosial, yang dirancang untuk membantu individu-individu dan kelompok-kelompok agar mencapai tingkat hidup dan kesehatan yang memuaskan. Maksudnya agar tercipta hubunganhubungan personal dan sosial yang memberi kesempatan kepada individu-individu pengembangan kemampuan-kemampuan mereka seluas-luasnya dan meningkatkan kesejahteraan mereka sesuai dengan kebutuhan-kebutuhan masyarakat. Sedangkan menurut Midgley (1995:14) Kondisi kesejahteraan sosial diciptakan atas kompromi tiga elemen. Pertama, sejauh mana masalah-masalah sosial ini diatur, kedua sejauh mana kebutuhan-kebutuhan dipenuhi, ketiga sejauh mana kesempatan untuk meningkatkan taraf hidup dapat disediakan.

Konsep kesejahteraan menurut Nasikun (1993) dapat dirumuskan sebagai padanan makna dari konsep martabat manusia yang dapat dilihat dari empat indicator yaitu : (1) rasa aman (security), (2) Kesejahteraan (welfare), (3) Kebebasan (freedom), dan (4) jati diri (Identity.

Dalam memahami realitas tingkat kesejahteraan, pada dasarnya terdapat beberapa faktor yang menyebabkan terjadinya kesenjangan tingkat kesejahteraan antara lain : (1) social ekonomi rumah tangga atau masyarakat, (2) struktur kegiatan ekonomi sektoral yang menjadi dasar kegiatan produksi rumah tangga atau masyarakat, (3) potensi regional (sumberdaya alam, lingkungan dan insfrastruktur) yang mempengaruhi perkembangan struktur kegiatan produksi, dan (4) kondisi kelembagaan yang membentuk jaringan kerja produksi dan pemasaran pada skala lokal, regional dan global (Taslim, 2004).

\section{METODOLOGI PENELITIAN \\ Metode yang digunakan dalam}

penelitian ini adalah metode penelitian deskriptif.Melalui metode penelitian deskriptif, penulis berusaha mendeskripsikan tentang pemberdayaan masyarakat melalui PPIP dalam meningkatkan kesejahteraan masyarakat Kecamatan Wanasalam Kabupaten Lebak. Dengan pemilihan rancangan deskriptif kualitatif, maka penulis akan melakukan pendekatan terhadap obyek penelitian dengan menggali informasi sesuai dengan persepsi penulis dan informan dan dapat berkembang sesuai dengan interaksi yang terjadi dalam proses wawancara.

Penulissenantiasa menginterpretasikan makna yang tersurat dan tersirat dari penjelasan yang diberikan informan, hasil observasi lapangan serta catatan pribadi.Definisi operasional dan indikatorindikator yang diteliti dalam penelitian tentang pemberdayaan masyarakat melalui PPIP dalam meningkatkan kesejahteraan masyarakat Kecamatan Wanasalam Kabupaten Lebak ini berdasarkan kepada prinsip-prinsip pemberdayaan masyarakat berdasarkan teori dari Dahama dan Bhatnagar dalam Mardikanto (2013)

Teknik pengumpulan data yang dikumpulkan terdiri atas data primer dan data skunder.Dataprimer merupakan data yang langsung dikumpulkan pada saat 
melaksanakan penelitian di lapangan berupa wawancara, pengamatan langsung melalui komunikasi yang tidak secara langsung tentang pokok masalah.Sedangkan data sekunder adalah data yang merupakan hasil pengumpulan orang atau instansi dalam bentuk publikasi, laporan, dokumen, dan buku-buku lainnya yang berkaitan dengan penelitian ini.Data primer berasal dari informan. Informan yang dipilih adalah unsur Camat Wanasalam, Perangkat Kecamatan, Kepala Desa, Badan Perwakilan Desa (BPD), Perwakilan dari

Masyarakat/stakeholders (Tokoh masyarakat, tokoh agama, tokoh wanita/PKK), Organisasi Masyarakat Setempat (OMS), Kelompok Pemanfaat dan Pemelihara (KPP), Kader Desa (KD) dan yang terlibat dalam proses perencanaan pembangunan. Data skunder diambil dari beberapa dokumen atau catatan yang berasal dari instansi yang terkait, hasil penelitian sejenis maupun publikasi buku-buku yang menunjang pembahasan penelitian.

\section{HASIL PENELITIAN DAN PEMBAHASAN}

Pemberdayaan merupakan upaya untuk meningkatkan kapasitas masyarakat dan pemberian kesempatan yang seluas-luasnya bagi penduduk kategori miskin untuk melakukan kegiatan sosial ekonomi yang produktif, sehingga mampu menghasilkan nilai tambah yang lebih tinggi dan pendapatan yang lebih besar. Dengan demikian, pemberdayaan masyarakat pada hakekatnya diarahkan untuk meningkatkan akses hidup sejahtera bagi individu, keluarga dan kelompok masyarakat terhadap sumber daya untuk melakukan proses produksi dan kesempatan berusaha. Untuk dapat mencapai hal tersebut diperlukan berbagai upaya untuk memotivasi dalam bentuk antara lain bantuan modal dan pengembangan sumber daya manusia.

Program Pembangunan Infrastruktur

Perdesaan(PPIP)yang direncanakan merupakan bentuk pengembangan dari model perencanaan pembangunan yang berpihak padapembangunan manusia khususnya masyarakat miskin di

Kecamatan Wanasalam Kabupaten Lebak.Dalam memantau dan melakukan analisis bagaimana keberhasilan dan indikator pemberdayaan masyarakat peneliti melakukan analisis berdasarkan teori indikator-indikator dan prinsip-prinsip

pemberdayaan masyarakat yang dikemukakan oleh Dahama dan Bhatnagar dalam Mardikanto (2013) yang dipakai untuk mengukur pelaksanaan pemberdayaan masyarakat yaitu :

1. Analisis Minat dan kebutuhan Minat dan kebutuhan tersebut harus berdasarkan minat dan kebutuhan yang dirasakan (felt need) artinya program yang akan dirumuskan harus bertolak dari minat dan kebutuhan-kebutuhan yang telah dirasakan oleh masyarakat sehingga program itu benar-benar dirasakan sebagai pemecahan masalah atau pencapaian tujuan yang dikehendaki.Dari hasil wawancara dapat dikemukakan bahwa kebutuhan infrastruktur sudah sesuai dengan minat dan kebutuhan masyarakat, selanjutnya dapat dikemukakan bahwa minat dan kebutuhan masyarakat sudah dilakukan berdasarkan prioritas pemilihan usulan kegiatan minat dan kebutuhan masyarakat, hal ini dilaksanakan pada kegiatan Musyawarah Desa II sebagai bagian dari tahapan perencanaan partisipatif masyarakat dalam penentuan minat dan jenis kebutuhan infrastruktur yang akan dibangun sebagaimana diuraikan pada tabel berikut ini : 


\section{Tabel 1}

Analisis Prioritas Usulan Kegiatan/

Minat dan Kebutuhan Masyarakat

\begin{tabular}{|c|c|c|c|c|c|c|c|c|c|}
\hline \multirow{2}{*}{ No } & \multirow[b]{2}{*}{ Aspek Penilaian } & \multirow[b]{2}{*}{ Nilai } & \multicolumn{7}{|c|}{ Usulan Kegiatan Masyarakat } \\
\hline & & & $\begin{array}{c}\text { Pengas } \\
\text { palan }\end{array}$ & $\begin{array}{l}\text { Rabat } \\
\text { Beton }\end{array}$ & $\begin{array}{c}\text { Paving } \\
\text { Block }\end{array}$ & Telford & MCK & $\begin{array}{c}\text { Air } \\
\text { Bersih }\end{array}$ & $\begin{array}{l}\text { Drai } \\
\text { nase }\end{array}$ \\
\hline 1. & $\begin{array}{l}\text { Kegiatan mendukung } \\
\text { peningkatan ekonomi dan } \\
\text { menjadi akses langsung } \\
\text { terhadap pemanfaat potensi } \\
\text { (pertanian, perkebunan, } \\
\text { perikanan, sumber air baku, } \\
\text { dll) yang ada di desa } \\
\text { a. Sangat mendukung } \\
\text { b. Mendukung } \\
\text { c. Tidak }\end{array}$ & $\begin{array}{l}A=3 \\
B=2 \\
C=1\end{array}$ & 2 & 2 & 2 & 3 & 1 & 3 & 1 \\
\hline 2. & $\begin{array}{ll}\text { Penerima Manfaat } \\
\text { a. } & <1 / 3 \text { jumlah penduduk } \\
\text { b. } & \text { Antara } 1 / 3 \text { s.d. } 2 / 3 \\
& \text { jumlah penduduk } \\
\text { c. } & >\text { dua pertiga jumlah } \\
& \text { penduduk } \\
\end{array}$ & $\begin{array}{l}A=1 \\
B=2 \\
C=3\end{array}$ & 2 & 2 & 1 & 2 & 2 & 1 & 1 \\
\hline 3. & $\begin{array}{l}\text { Manfaat dirasakan secara } \\
\text { langsung oleh masyarakat } \\
\text { a. Ya } \\
\text { b. Tidak }\end{array}$ & $\begin{array}{l}A=3 \\
B=1\end{array}$ & 3 & 3 & 3 & 3 & 3 & 1 & 3 \\
\hline 4. & $\begin{array}{l}\text { Ketersediaan Lahan } \\
\text { a. } \begin{array}{l}\text { Ada, dari lahan } \\
\text { eksisting }\end{array} \\
\text { b. Ada, namun berupa } \\
\text { ruang/fasilitas umum } \\
\text { c. } \quad \text { Tidak tersedia } \\
\end{array}$ & $\begin{array}{l}A=3 \\
B=2 \\
C=1\end{array}$ & 2 & 3 & 1 & 3 & 1 & 1 & 3 \\
\hline 5. & $\begin{array}{l}\text { Lokasi kegiatan berada pada } \\
\text { kantung-kantung kemiskinan } \\
\text { a. Ya } \\
\text { b. Tidak } \\
\end{array}$ & $\begin{array}{l}\mathbf{A}=\mathbf{3} \\
\mathbf{B}=\mathbf{1}\end{array}$ & 3 & 3 & 3 & 3 & 3 & 1 & 3 \\
\hline 6. & $\begin{array}{l}\text { Besarnya biaya } \\
\text { a. } \quad<250 \text { juta } \\
\text { b. } \quad \mathbf{2 5 0}-\mathbf{3 0 0} \text { juta } \\
\text { c. } \quad>300 \text { juta } \\
\end{array}$ & $\begin{array}{l}A=3 \\
B=2 \\
C=1\end{array}$ & 1 & 3 & 3 & 3 & 3 & 3 & 1 \\
\hline 7. & \begin{tabular}{ll}
\multicolumn{2}{l}{ Metode Pengerjaan } \\
a. & Teknologi sederhana \\
b. & Memerlukan peralatan \\
& berat \\
\end{tabular} & $\begin{array}{l}A=3 \\
B=1\end{array}$ & 1 & 3 & 3 & 3 & 3 & 3 & 3 \\
\hline 8.a. & $\begin{array}{l}\text { Waktu Pelaksanaan } \\
\quad<3 \text { bulan } \\
\text { b. } \quad>3 \text { bulan }\end{array}$ & $\begin{array}{l}\mathbf{A}=\mathbf{3} \\
\mathbf{B}=\mathbf{1}\end{array}$ & 3 & 3 & 3 & 3 & 1 & 3 & 1 \\
\hline \multicolumn{2}{|c|}{ TOTAL NILAI } & & 17 & 22 & 19 & 23 & 17 & 16 & 16 \\
\hline \multicolumn{2}{|c|}{ PERINGKAT } & & 4 & 2 & 3 & 1 & 5 & 6 & 7 \\
\hline
\end{tabular}

(Sumber : Hasil penelitian lapangan, 2015) 
Tabel 2

Analisis Prioritas Usulan Kegiatan/ Minat dan Kebutuhan Masyarakat Desa Cisarap

\begin{tabular}{|c|c|c|c|c|c|c|c|c|c|}
\hline \multirow[b]{2}{*}{ No } & \multirow[b]{2}{*}{ Aspek Penilaian } & \multirow[b]{2}{*}{ Nilai } & \multicolumn{7}{|c|}{ Usulan Kegiatan } \\
\hline & & & $\begin{array}{c}\text { Pengas } \\
\text { palan }\end{array}$ & $\begin{array}{l}\text { Rabat } \\
\text { Beton }\end{array}$ & $\begin{array}{c}\text { Paving } \\
\text { Block }\end{array}$ & Telford & MCK & $\begin{array}{c}\text { Air } \\
\text { Bersih }\end{array}$ & $\begin{array}{l}\text { Drai } \\
\text { nase }\end{array}$ \\
\hline 1. & $\begin{array}{l}\text { Kegiatan mendukung } \\
\text { peningkatan ekonomi dan } \\
\text { menjadi akses langsung } \\
\text { terhadap pemanfaat potensi } \\
\text { (pertanian, perkebunan, } \\
\text { perikanan, sumber air baku, } \\
\text { dil) yang ada di desa } \\
\text { a. Sangat mendukung } \\
\text { b. Mendukung } \\
\text { c. Tidak } \\
\end{array}$ & $\begin{array}{l}A=3 \\
B=2 \\
C=1\end{array}$ & 2 & 3 & 2 & 2 & 1 & 2 & 1 \\
\hline 2. & \begin{tabular}{ll}
\multicolumn{2}{l}{ Penerima Manfaat } \\
a. & <sepertiga jumlah \\
& penduduk \\
b. & Antara $1 / 3$ s.d. $2 / 3$ \\
& jumlah penduduk \\
c. & $>$ dua pertiga jumlah \\
& penduduk
\end{tabular} & $\begin{array}{l}A=1 \\
B=2 \\
C=3\end{array}$ & 2 & 3 & 1 & 2 & 2 & 1 & 1 \\
\hline 3. & $\begin{array}{l}\text { Manfaat dirasakan secara } \\
\text { langsung oleh masyarakat } \\
\text { a. Ya } \\
\text { b. Tidak } \\
\end{array}$ & $\begin{array}{l}\mathbf{A}=\mathbf{3} \\
\mathbf{B}=\mathbf{1}\end{array}$ & 3 & 3 & 3 & 3 & 3 & 1 & 3 \\
\hline 4. & $\begin{array}{l}\text { Ketersediaan Lahan } \\
\text { a. Ada, dari lahan eksisting } \\
\text { b. Ada, namun berupa } \\
\text { ruang/fasilitas umum } \\
\text { c. Tidak tersedia } \\
\end{array}$ & $\begin{array}{l}A=3 \\
B=2 \\
C=1\end{array}$ & 2 & 3 & 1 & 3 & 1 & 1 & 3 \\
\hline 5. & $\begin{array}{l}\text { Lokasi kegiatan berada pada } \\
\text { kantung-kantung kemiskinan } \\
\text { a. Ya } \\
\text { b. Tidak }\end{array}$ & $\begin{array}{l}A=3 \\
B=1\end{array}$ & 3 & 3 & 3 & 1 & 3 & 1 & 3 \\
\hline 6. & $\begin{array}{l}\text { Besarnya biaya } \\
\text { a. } \quad<250 \text { juta } \\
\text { b. } \quad 250-300 \text { juta } \\
\text { c. } \quad>300 \text { juta } \\
\end{array}$ & $\begin{array}{l}A=3 \\
B=2 \\
C=1\end{array}$ & 1 & 3 & 3 & 3 & 3 & 3 & 1 \\
\hline 7. & \begin{tabular}{ll}
\multicolumn{2}{l}{ Metode Pengerjaan } \\
a. & Teknologi sederhana \\
b. & Memerlukan peralatan \\
& berat \\
\end{tabular} & $\begin{array}{l}A=3 \\
B=1\end{array}$ & 1 & 3 & 3 & 3 & 3 & 3 & 3 \\
\hline 8. & $\begin{array}{l}\text { Waktu Pelaksanaan } \\
\text { a. <3 bulan } \\
\text { b. >3 bulan }\end{array}$ & $\begin{array}{l}A=3 \\
B=1\end{array}$ & 3 & 3 & 3 & 3 & 1 & 3 & 1 \\
\hline \multicolumn{2}{|c|}{ TOTAL NILAI } & & 17 & 24 & 19 & 21 & 17 & 16 & 16 \\
\hline PERI & NGKAT & & 4 & 1 & 3 & 2 & 5 & 6 & 7 \\
\hline
\end{tabular}

(Sumber : Hasil penelitian lapangan, 2015) 
Tabel 3

Analisis Prioritas Usulan Kegiatan/ Minat dan Kebutuhan Masyarakat Desa Parungsari

\begin{tabular}{|c|c|c|c|c|c|c|c|c|c|}
\hline \multirow[b]{2}{*}{ No. } & \multirow[b]{2}{*}{ Aspek Penilaian } & \multirow[b]{2}{*}{ Nilai } & \multicolumn{7}{|c|}{ Usulan Kegiatan } \\
\hline & & & $\begin{array}{c}\text { Pengas } \\
\text { palan }\end{array}$ & $\begin{array}{l}\text { Rabat } \\
\text { Beton }\end{array}$ & $\begin{array}{c}\text { Paving } \\
\text { Block }\end{array}$ & Telford 1 & MCK & $\begin{array}{c}\text { Air } \\
\text { Bersih }\end{array}$ & Drainase \\
\hline 1. & $\begin{array}{l}\text { Kegiatan mendukung } \\
\text { peningkatan ekonomi dan } \\
\text { menjadi akses langsung terhadap } \\
\text { pemanfaat potensi ( pertanian, } \\
\text { perkebunan, perikanan, sumber } \\
\text { air baku, dll) yang ada di desa } \\
\text { a. Sangat mendukung } \\
\text { b. Mendukung } \\
\text { c. Tidak }\end{array}$ & $\begin{array}{l}A=3 \\
B=2 \\
C=1\end{array}$ & 2 & 2 & 2 & 3 & 1 & 3 & 1 \\
\hline 2. & $\begin{array}{ll}\text { Penerima Manfaat } \\
\text { a. } & \begin{array}{l}<\text { sepertiga jumlah } \\
\text { penduduk }\end{array} \\
\text { b. } & \begin{array}{l}\text { Antara sepertiga s.d. } \\
\text { duapertiga jumlah }\end{array} \\
\text { penduduk } & \begin{array}{l}\text { pdua pertiga jumlah } \\
\text { penduduk }\end{array} \\
\text { c. }\end{array}$ & $\begin{array}{l}A=1 \\
B=2 \\
C=3\end{array}$ & 2 & 2 & 1 & 2 & 2 & 1 & 1 \\
\hline 3. & $\begin{array}{l}\text { Manfaat dirasakan secara } \\
\text { langsung oleh masyarakat } \\
\text { a. Ya } \\
\text { b. Tidak }\end{array}$ & $\begin{array}{l}\mathbf{A}=\mathbf{3} \\
\mathbf{B}=\mathbf{1}\end{array}$ & 3 & 3 & 3 & 3 & 3 & 1 & 3 \\
\hline 4. & $\begin{array}{l}\text { Ketersediaan Lahan } \\
\text { a. Ada, dari lahan eksisting } \\
\text { b. Ada, namun berupa } \\
\text { ruang/fasilitas umum } \\
\text { c. } \quad \text { Tidak tersedia } \\
\end{array}$ & $\begin{array}{l}A=3 \\
B=2 \\
C=1\end{array}$ & 2 & 3 & 1 & 3 & 1 & 1 & 3 \\
\hline 5. & $\begin{array}{l}\text { Lokasi kegiatan berada pada } \\
\text { kantung-kantung kemiskinan } \\
\text { a. Ya } \\
\text { b. Tidak }\end{array}$ & $\begin{array}{l}\mathbf{A}=\mathbf{3} \\
\mathbf{B}=\mathbf{1}\end{array}$ & 3 & 3 & 3 & 3 & 3 & 1 & 3 \\
\hline 6. & $\begin{array}{l}\text { Besarnya biaya } \\
\text { a. } \quad<250 \text { juta } \\
\text { b. } \quad 250-300 \text { juta } \\
\text { c. } \quad>300 \text { juta } \\
\end{array}$ & $\begin{array}{l}A=3 \\
B=2 \\
C=1\end{array}$ & 1 & 3 & 3 & 3 & 3 & 3 & 1 \\
\hline 7. & $\begin{array}{ll}\text { Metode Pengerjaan } \\
\text { a. } & \text { Teknologi sederhana } \\
\text { b. } & \text { Memerlukan peralatan } \\
& \text { berat. } \\
\end{array}$ & $\begin{array}{l}A=3 \\
B=1\end{array}$ & 1 & 3 & 3 & 3 & 3 & 3 & 3 \\
\hline 8. & $\begin{array}{l}\text { Waktu Pelaksanaan } \\
\text { a. } \quad<3 \text { bulan } \\
\text { b. } \quad>3 \text { bulan }\end{array}$ & $\begin{array}{l}\mathbf{A}=\mathbf{3} \\
\mathbf{B}=\mathbf{1}\end{array}$ & 3 & 3 & 3 & 3 & 1 & 3 & 1 \\
\hline \multicolumn{2}{|c|}{ TOTAL NILAI } & & 17 & 22 & 19 & 23 & 17 & 16 & 16 \\
\hline \multicolumn{2}{|c|}{$\begin{array}{l}\text { PERINGKAT } \\
\end{array}$} & & 4 & 2 & 3 & $\overline{1}$ & 5 & 6 & 7 \\
\hline
\end{tabular}

(Sumber : Hasil penelitian lapangan, 2015) 
Dari uraian di atas maka dapat disimpulkan bahwa indikator minat dan kebutuhan masyarakat sudah mendapatkan perhatian dan dilaksanakan dengan baik, minat dan kebutuhan tersebut sudah sesuai dengan keinginan masyarakat dan selaras dengan rencana kerja program yang

diimplementasikan dalam bentuk pembangunan infrastruktur, dengan demikian indikator dan prinsip-prinsip pemberdayaan masyarakat berdasarkan analisis minat dan kebutuhan sudah dilaksanakan.

\section{Analisis Pengorganisasian masyarakat \\ Menurut Ross dalam Aprillia} Theresia (2014:237) pengorganisasian masyarakat adalah suatu proses dimana masyarakat mengidentifikasi kebutuhankebutuhan atau tujuan-tujuannya, mengembangkan kepercayaan diri dan kemauan untuk bekerja dalam memenuhi kebutuhan, menemukan sumber daya (internal/eksternal) untuk menangani kebutuhan-kebutuhan, mengambil tindakan dan mengembangkan sikap kooperatif dan kolaboratif dan praktik di masyarakat.
Tujuan utama pengorganisasian masyarakat bawah adalah untuk memperbaiki kualitas hidup masyarakat melalui pendayagunaan sumber-sumber yang ada pada mereka serta menekankan pada prinsip partisipasi sosial.

Dan dari hasil wawancara dapat disampaikan bahwa pengorganisasian masyarakat sudah menjadi prioritas setiap tahapan kegiatan Program Pembangunan Infrastruktur Perdesaan (PPIP) dan berdasarkan hasil temuan di lapangan dapat dikemukakan pengorganisasian dan pemberdayaan masyarakat sudah dilakukan melalui proses kegiatan Musyawarah Desa I yang memilih dan menetapkan Organisasi Masyarakat Setempat (OMS), Kelompok Pemanfaat dan Pemelihara (KPP) dan Kader Desa (KD) sebagai organisasi masyarakat yang berperan dalam

perencanaan dan pelaksanaan pembangunan. Susunan OMS terdiri dari ketua, bendahara, sekretaris, tenaga teknis dan anggota dengan keanggotaan minimal $30 \%$ perempuan. Organisasi Masyarakat Setempat (OMS).

Struktur Organisasi OMS dapat digambarkan sebagai berikut :

\section{Gambar 1 Struktur Organisasi OMS}

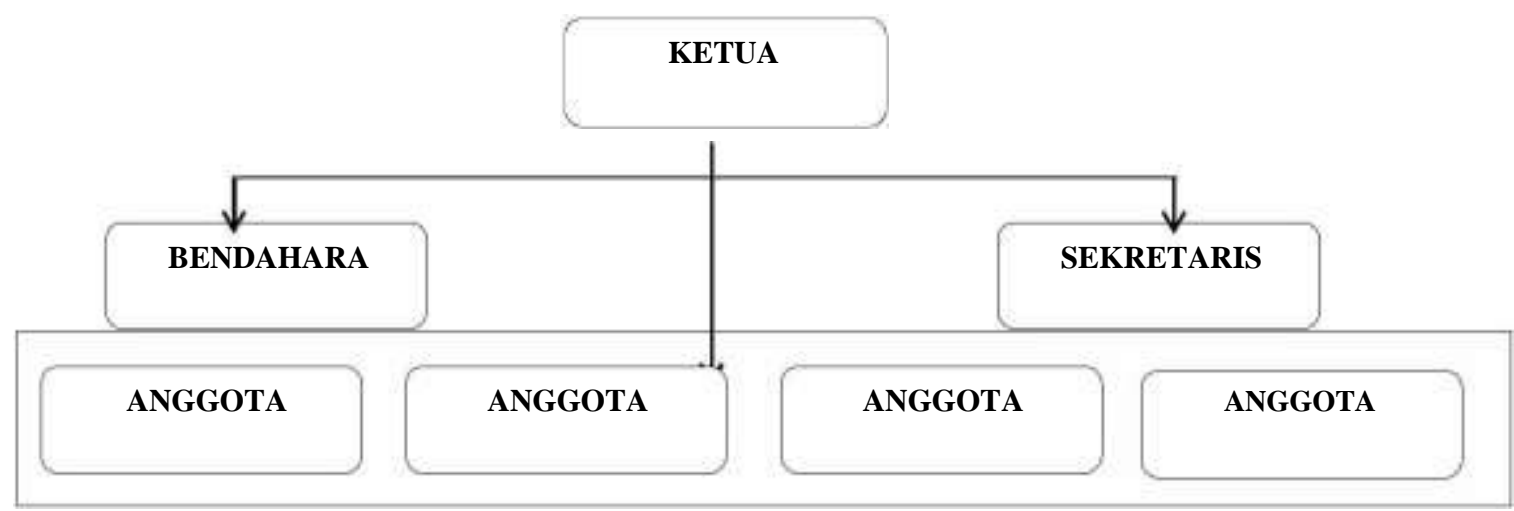

Sumber : Buku Pedoman Pelaksanaan PPIP, 2014

Dari uraian di atas dapat kemukakan pengorganisasian masyarakat sangat penting di dalam melaksanakan pembangunan infrastruktur berbasis masyarakat karena organisasi masyarakat merupakan instrumen institusional dimana kinerja pembangunan dapat diukur dan berdasarkan tujuan awal program pemberdayaan, maka program atau usaha ini dapat dikatakan telah efektif dikarenakan telah mencapai salah satu tujuannya yakni keterlibatan masyarakat bawah dimulai dari keluarga, kekerabatan dan persaudaraan sehingga keefektifan 
pemberdayaan dapat dilaksanakan. Dengan demikian dapat disimpulkan pemberdayaan masyarakat melalui Program Pembangunan Infrastruktur Perdesaan (PPIP) dalam meningkatkan kesejahteraan masyarakat Kecamatan Wanasalam Kabupaten Lebak sudah melaksanakan prinsip-prinsip pemberdayaan masyarakat berdasarkan analisis pengorganisasian masyarakat.

3. Analisis Keragaman Budaya Lokal.

Menurut Colletta dalam Aprillia

Theresia (2014:59) menguraikan pentingnya budaya lokal dalam proses pembangunan masyarakat yaitu :

1. Unsur-unsur budaya lokal mempunyai legitimasi tradisional di mata masyarakat binaan yang menjadi sasaran program pemberdayaan dan pembangunan;

2. Unsur-unsur budaya secara simbolis merupakan untuk komunikasi paling berharga dari penduduk setempat;

3. Unsur-unsur budaya mempunyai aneka ragam fungsi (baik terwujud maupun terpendam) yang sering menjadikannnya sebagai sarana yang paling berguna untuk perubahan dibandingkan dengan yang tampak pada permukaan jika hanya dilihat dalam kaitan dengan fungsinya yang berwujud

saja.

Berdasarkan data observasi lapangan, peneliti uraikan mengenai peta, profil masalah dan potensi sosial budaya dalam tabel berikut

Tabel 4

Peta, Profil Masalah dan

Potensi Sosial dan Budaya

\begin{tabular}{|c|c|c|c|c|c|c|}
\hline \multirow[b]{2}{*}{ No } & \multirow[b]{2}{*}{$\begin{array}{c}\text { Potensi Sosial } \\
\text { Budaya }\end{array}$} & \multirow[b]{2}{*}{$\begin{array}{l}\text { Prioritas } \\
\text { Masalah }\end{array}$} & \multirow[b]{2}{*}{$\begin{array}{c}\text { Lokasi } \\
\text { (Dusun) }\end{array}$} & \multicolumn{3}{|c|}{ Profil dan Karakteristik Masalah } \\
\hline & & & & $\begin{array}{l}\text { Nilai Sosial/ } \\
\text { Budaya/Adat }\end{array}$ & $\begin{array}{c}\text { Tingkat } \\
\text { Pendidikan/ } \\
\text { Pelatihan } \\
\end{array}$ & $\begin{array}{c}\text { Akses } \\
\text { Modal } \\
\text { Pasar }\end{array}$ \\
\hline 1. & Gapoktan & $\begin{array}{c}\text { Belum } \\
\text { optimalnya } \\
\text { hasil } \\
\text { produksi }\end{array}$ & $\begin{array}{c}\text { Desa Cisarap, Desa } \\
\text { Cilangkap dan } \\
\text { Desa Parungsari }\end{array}$ & $\begin{array}{c}\text { Belum mampu } \\
\text { menciptakan } \\
\text { sesuatu yg } \\
\text { ekonomis untuk } \\
\text { kebutuhan warga }\end{array}$ & $\begin{array}{c}\text { Pelatihan } \\
\text { khusus yang } \\
\text { perlu } \\
\text { digalakan }\end{array}$ & $\begin{array}{c}\text { Belum ada } \\
\text { dukungan } \\
\text { materiil dan } \\
\text { non materiil } \\
\text { dari pihak } \\
\text { terkait } \\
\end{array}$ \\
\hline 2. & Karang Taruna & $\begin{array}{c}\text { Kurang } \\
\text { berperan } \\
\text { aktif }\end{array}$ & $\begin{array}{l}\text { Desa Cisarap, Desa } \\
\text { Cilangkap dan } \\
\text { Desa Parungsari }\end{array}$ & $\begin{array}{c}\text { Kemampuan SDM } \\
\text { yang terbatas } \\
\text { sangat } \\
\text { menghambat } \\
\text { kegiatan } \\
\end{array}$ & $\begin{array}{c}\text { Tidak ada } \\
\text { pelatihan yang } \\
\text { memadai } \\
\text { sesuai } \\
\text { kebutuhan } \\
\end{array}$ & \\
\hline 3. & $\begin{array}{c}\text { Lembaga } \\
\text { pendidikan \& } \\
\text { keagamaan }\end{array}$ & $\begin{array}{c}\text { Kurang } \\
\text { sinergi } \\
\text { dengan } \\
\text { Pemdes dan } \\
\text { BPD }\end{array}$ & $\begin{array}{l}\text { Desa Cisarap, Desa } \\
\text { Cilangkap dan } \\
\text { Desa Parungsari }\end{array}$ & $\begin{array}{c}\text { Pemahaman } \\
\text { persepsi yang } \\
\text { harmonis }\end{array}$ & $\begin{array}{l}\text { Pembinaan } \\
\text { dari tokoh } \\
\text { masyarakat }\end{array}$ & \\
\hline
\end{tabular}

Sumber : Laporan Fasilitator Masyarakat, 2015

Berdasarkan hasil penelitian ditemukan fakta empiris di Kecamatan Wanasalam keragaman budaya setiap desa bersifat homogen sehingga lebih memudahkan masyarakat untuk ikut aktif berpartisipasi dalam setiap kegiatan pemberdayaan, dengan demikian dapat disimpulkan pemberdayaan masyarakat melalui Program Pembangunan
Infrastruktur Perdesaan (PPIP) dalam meningkatkan kesejahteraan masyarakat Kecamatan Wanasalam Kabupaten Lebak sudah melaksanakan prinsip-prinsip pemberdayaan masyarakat berdasarkan analisis keragaman budaya.

4. Analisis Perubahan budaya Mengenai perubahan budaya yang 
terjadi dalam proses pemberdayaan masyarakat, berikut hasil wawancara dengan fasilitator masyarakat selaku pendamping masyarakat dalam melaksanakan kegiatan PPIP di tingkat desa :

"Sebagai fasilitator, kami senantias melihat terlebih dahulu nilai-nilai budaya yang ada di desa sepert halhal yang tabu dan tidak diperbolehkan, tujuannya agar pendekatan pemberdayaan kepada masyarakat dalam pelaksanaan program dapat tercapai."(Sumber Informan : Fasilitator Masyarakat, 10 April 2015)

Dari hasil penelitian lapangan ditemukan bahwa nilai-nilai budaya yang berada di dalam masyarakat Kecamatan Wanasalam mempunyai hubungan yang sangat erat dengan pemberdayaan masyarakat. Kearifan lokal atau nilai-nilai budaya selalu dijadikan pedoman atau acuan oleh masyarakat dalam bertindak atau berperilaku dalam praktek kehidupannya sehingga mempunyai dampak positif terhadap pemberdayaan masyarakat karena nilai-nilai budaya tersebut memberikan input bagi kegiatan pemberdayaan masyarakat atau dapat diartikan pemberdayaan masyarakat sudah menyesuaikan dengan perubahan budaya setempat.

Berdasarkan uraian di atas, pemberdayaan masyarakat berdasarkan analisis perubahan budaya sudah memberikan kontribusi positif terhadap pemberdayaan masyarakat.

5. Analisis Kerjasama dan partisipasi Slamet dalam Aprilia Theresia (2014:207) menguraikan bahwa tumbuh berkembangnya partisipasi masyarakat dalam pembangunan sangat ditentukan halhal seperti : adanya kesempatan yang diberikan kepada masyarakat untuk berpartisipasi, adanya kemauan masyarakat dan adanya kemampuan masyarakat untuk berpartisipasi. Dilihat dari tingkatan partisipasi masyarakat, Wilcox dalam Aprillia Theresia (2014:202) mengemukakan sebagai berikut :

Gambar 2

Jenjang Tingkat Partisipasi

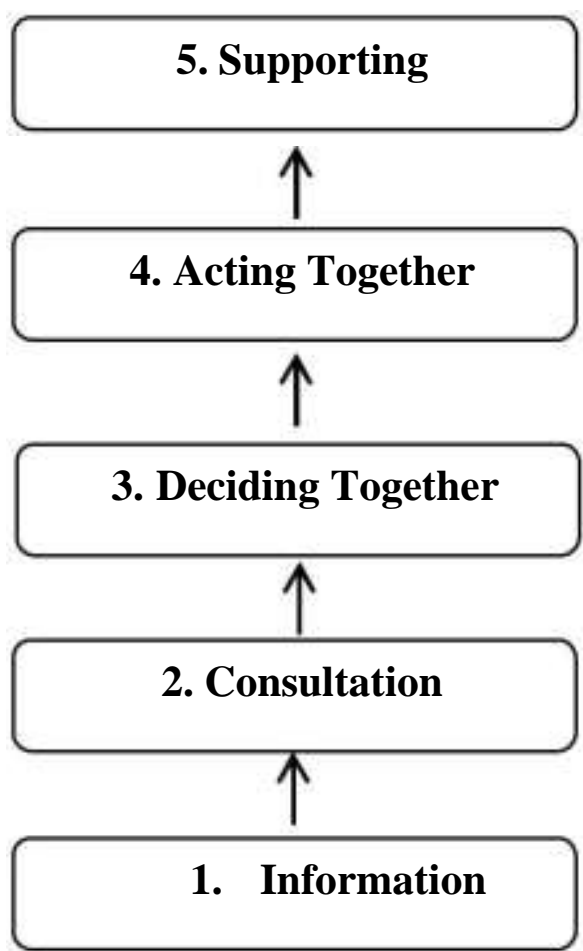

Sumber : Wilcox, 2014 
1. Information, memberikan Informasi;

2. Consultation, memberikan pendapat sebagai pendengar yang baik untuk memberikan umpan balik tetapi tidak terlibat dalam implementasi ide dan gagasan;

3. Deciding Together, pengambilan keputusan bersama, dalam arti memberikan dukungan terhadap ide, gagasan,pilihan-pilihanserta mengembangkanpeluangyang diperlukan guna pengambilan keputusan;

4. Acting together, bertindak bersama dalam arti tidak sekedar ikut dalam pengambilan keputusan tetapi juga terlibat dan menjalin kemitraan dalam pelaksanaan kegiatannya;

5. Supporting, memberikan dukungan dimana kelompok-kelompok lokal menawarkan pendanaan, nasehat dan

\section{dukungan lain untuk}

mengembangkan agenda kegiatan.

Selanjutnya hasil wawancara yang dilakukan dengan Kepala Desa mengatakan sebagai berikut :

"Ketidakhadiran masyarakat terutama kaum perempuan dalam kegiatan musyawarah desa karena masyarakat sibuk dengan aktivitas di siang hari dan masyarakat cenderung pasif kalaupun hadir dalam setiap pertemuan atau musyawarah desa. "(Sumber Informan : Tokoh Masyarakat/Agama, 11 April 2015)

Untuk melengkapi data wawancara di atas peneliti menguraikan data tingkat partisipasi masyarakat dalam kegiatan PPIP yaitu sebagai berikut :

Tabel 5

Monitoring Partisipasi Masyarakat

Dalam Perencanaan Tingkat Desa

\begin{tabular}{|c|c|c|c|c|}
\hline \multirow{2}{*}{ Kegiatan } & \multirow{2}{*}{ Uraian } & \multicolumn{3}{|c|}{ Nama Desa Sasaran } \\
\hline & & Cisarap & Cilangkap & Parungsari \\
\hline \multirow{5}{*}{ Sosialisasi } & Jumlah Undangan & 45 & 40 & 45 \\
\hline & Jumlah Total Peserta & 34 & 36 & 31 \\
\hline & Jumlah Peserta Perempuan & 10 & 26 & 6 \\
\hline & Jumlah Masyarakat Miskin yang hadir & 36 & 24 & 27 \\
\hline & Jumlah Total KK & 959 & 577 & 697 \\
\hline \multirow{5}{*}{$\begin{array}{l}\text { Musyawarah } \\
\text { Desa I }\end{array}$} & Jumlah Undangan & 55 & 60 & 50 \\
\hline & Jumlah Total Peserta & 49 & 52 & 41 \\
\hline & Jumlah Peserta Perempuan & 8 & 15 & 4 \\
\hline & Jumlah Masyarakat Miskin yang hadir & 41 & 47 & 31 \\
\hline & Jumlah Total KK & 959 & 577 & 697 \\
\hline \multirow{4}{*}{$\begin{array}{c}\text { Musyawarah } \\
\text { Desa II }\end{array}$} & Jumlah Undangan & 135 & 60 & 95 \\
\hline & Jumlah Total Peserta & 125 & 56 & 83 \\
\hline & Jumlah Peserta Perempuan & 40 & 21 & 20 \\
\hline & Jumlah Masyarakat Miskin yang hadir & 110 & 48 & 71 \\
\hline \multirow{5}{*}{$\begin{array}{c}\text { Musyawarah } \\
\text { Desa III }\end{array}$} & Jumlah Undangan & 85 & 60 & 95 \\
\hline & Jumlah Total Peserta & 82 & 57 & 88 \\
\hline & Jumlah Peserta Perempuan & 23 & 16 & 19 \\
\hline & Jumlah Masyarakat Miskin yang hadir & 78 & 49 & 81 \\
\hline & Jumlah Total KK & 959 & 577 & 697 \\
\hline
\end{tabular}

Sumber : Fasilitator Masyarakat, Tahun 2015 
Berdasarkan tabel monitoring partisipasi dalam perencanaan tingkat desa di atas dapat diketahui jumlah kehadiran masyarakat masing-masing desa dalam setiap kegiatan musyawarah desa cukup rendah dan apabila dibandingkan dengan jumlah total Kepala Keluarga (KK) di satu desa maka rata-rata presentase kehadiran masyarakat dalam kegiatan sosialisasi desa sebesar 4,74 persen, rata-rata tingkat partisipasi kegiatan Musyawarah Desa I sebesar 6,67 persen, rata-rata tingkat partisipasi kegiatan Musyawarah Desa II sebesar 11,55 persen dan rata-rata tingkat partisipasi kegiatan Musyawarah Desa III sebesar 10,35 persen.Dengan demikian dapat disimpulkan prinsip-prinsip pemberdayaan masyarakat berdasarkan analisis kerja sama dan partisipasi belum dilaksanakan.

\section{Analisis Demokrasi dan penerapan ilmu}

Menurut Freire dalam Mardikanto (2013:210) terkait dengan metode pemberdayaan bahwa kegiatan pendidikan orang dewasa merupakan proses penyadaran menuju kepada pembebasan oleh sebab itu proses pemberdayaan harus dibebaskan dari upaya-upaya menciptakan ketergantungan atau bentukbentuk penindasan baru artinya melalui pemberdayaan penerima manfaat harus diberi kesempatan seluas-luasnya untuk menyampaikan pengalaman dan mengembangkan daya nalarnya sehingga dalam proses pemberdayaan tersebut kedudukan fasilitator (sebagai pendidik) dan penerima manfaat (yang dididik) berada dalam situasi yang setara.

Berdasarkan wawancara ditemukan fakta empiris bahwa dalam proses demokrasi (metode pemberdayaan) dan pengambilan keputusan dalam kegiatan musyawarah desa masyarakat cenderung bersikap pasif dan menerima saja hasil keputusan seperti dalam wawancara berikut ini dengan anggota masyarakat :

"Sebagai warga masyarakat, kami nurut saja dengan apa kata pimpinan (dalam hal ini kepala desa dan aparat desa), karena mereka lebih tahu dan paham tentang apa kebutuhan yang harus dipenuhi dari warganya. '(Sumber Informan : Anggota Masyarakat, 11 April 2015)

Tabel 6

Pemantauan Partisipasi Masyarakat Dalam setiap Kegiatan

\begin{tabular}{|c|c|c|c|c|}
\hline \multirow[t]{2}{*}{ Kegiatan } & \multicolumn{3}{|c|}{$\begin{array}{c}\text { Kualitas Partisipasi dalam } \\
\text { demokrasi dan pengambilan } \\
\text { keputusan }\end{array}$} & \multirow[t]{2}{*}{$\begin{array}{l}\text { Komentar } \\
\text { Umum }\end{array}$} \\
\hline & Sangat aktif & Aktif & Rendah & \\
\hline Musyawarah Desa I & & & $\sqrt{ }$ & \\
\hline Identifikasi Permasalahan & & $\sqrt{ }$ & & \\
\hline Musyawarah Desa II & & & $\sqrt{ }$ & \\
\hline Penyusunan UPD dan RKM & & & $\sqrt{ }$ & \\
\hline Musyawarah Desa III & & & $\sqrt{ }$ & \\
\hline $\begin{array}{l}\text { Pelaksanaan Kegiatan (Tenaga kerja, } \\
\text { pengadaan bahan dan material) }\end{array}$ & & $\sqrt{ }$ & & \\
\hline Musyawarah Desa IV & & & $\sqrt{ }$ & \\
\hline $\begin{array}{l}\text { Pelestarian (Jumlah orang yang } \\
\text { berpartisipasi dalam kegiatan pelestarian) }\end{array}$ & & & $\sqrt{ }$ & \\
\hline
\end{tabular}

Sumber : Laporan Fasilitator Masyarakat, tahun 2015 
Proses penyadaran ini perlu pula mengkaji problem-problem yang dihadapi oleh masyarakat miskin, sehingga solusi yang diberikan benar-benar sesuai dengan kondisi dan potensi yang ada pada diri mereka. Dengan demikian pemberdayaan masyarakat melalui Program Pembangunan Infrastruktur Perdesaan (PPIP) dalam meningkatkan kesejahteraan masyarakat Kecamatan Wanasalam Kabupaten Lebak belum melaksanakan prinsip-prinsip pemberdayaan masyarakat berdasarkan analisis demokrasi dan penerapan ilmu.

\section{Analisis Belajar sambil bekerja}

Dalam kaitan ini, menurut

Mardikanto (2013:68), inti dari kegiatan pemberdayaan yang bertujuan untuk mewujudkan perubahan adalah terwujudnya proses belajar yang mandiri untuk terus-menerus melakukan perubahan. Dengan perkataan lain, pemberdayaan harus didesain sebagai proses belajar atau dalam setiap upaya pemberdayaan harus terkandung upaya-upaya pembelajaran dan penyelenggaraan pelatihan.

\section{Tabel 7}

Mat

riks Analisis Belajar sambil bekerja

\begin{tabular}{|c|c|c|c|}
\hline No & Kegiatan & Progres dan Hasil Kegiatan & Keterlibatan Masyarakat \\
\hline 1. & $\begin{array}{l}\text { Identifikasi } \\
\text { Permasalahan dan } \\
\text { pemetaan Desa }\end{array}$ & $\begin{array}{ll}\circ & \text { Tersusunnya kondisi Demografi desa; } \\
\circ & \text { Tersusunnya peta dan Profil Keluarga } \\
& \text { Miskin; } \\
\circ & \text { Tersusunnya peta dan Profil Relawan dan } \\
& \text { Sumber Daya; } \\
& \text { Tersusunnya peta dan Profil Masalah } \\
& \text { Infrastruktur; } \\
\text { Tersusunnya peta dan Profil Masalah dan } \\
\text { Potensi Ekonomi; } \\
\text { Tersusunnya peta dan Profil Masalah dan } \\
\text { Potensi Sosial dan Budaya; } \\
\end{array}$ & $\begin{array}{ll}- & \text { Organisasi Masyarakat dan } \\
\text { Kader Desa menjadi } \\
\text { koordinator pemetaan } \\
\text { Masyarakat menjadi relawan } \\
\text { di lapangan dengan ikut aktif } \\
\text { melakukan identifikasi dan } \\
\text { pemetaan dengan didampingi } \\
\text { oleh FM. }\end{array}$ \\
\hline 2 & $\begin{array}{l}\text { Penyusunan } \\
\text { Rencana Kegiatan } \\
\text { Masyarakat }\end{array}$ & $\begin{array}{ll}\text { a. } & \text { Usulan rencana pembangunan } \\
\text { infrastruktur } & \\
\text { b. Usulan rencana operasi dan pemeliharaan } \\
\text { c. Usulan rencana pembiayaan operasi dan } \\
\text { pemeliharaan }\end{array}$ & $\begin{array}{l}\text { Penyusunan dilakukan OMS, KPP } \\
\text { dan Kader Desa }\end{array}$ \\
\hline
\end{tabular}

Sumber : Laporan OMS Desa Cisarap, tahun 2015

dengan ketua Organisasi Masyarakat Setempat (OMS) ditemukan adanya fakta bahwa pemberdayaan dilakukan dengan pembelajaran nyata kepada masyarakat, yaitu sebagai berikut :

"Dalam pelaksanaan kegiatan
pemberdayaan masyarakat dari
fasilitator kepada masyarakat terlihat
cukup antusias, fasilitator memberikan
bimbingan dan pembinaan misalnya
bagaimana membuat laporan keuangan
dan melakukan pemetaan
wilayah."(Sumber Informan :
Organisasi Masyarakat Setempat
(OMS), 11 April 2015)

Dari hasil temuan lapangan, peneliti menguraikan data-data hasil observasi kegiatan pemberdayaan masyarakat terkait dengan bimbingan dan learning by doing Fasilitator Masyarakat dan masyarakat yaitu sebagai berikut : 
Dari hasil wawancara dan observasi di atas, maka peneliti dapat menyimpulkan kegiatan pemberdayaan masyarakat melalui belajar sambil bekerja yang dilakukan sudah berjalan dengan baik, masyarakat terlibat dan diberikan kesempatan untuk belajar dan dapat merasakan pengalaman nyata dan tidak hanya sekedar menerima informasi atau konsep-konsep teoritis tentang program, dengan demikian dapat disimpulkan pemberdayaan masyarakat melalui Program Pembangunan Infrastruktur Perdesaan (PPIP) sudah melaksanakan prinsip pemberdayaan masyarakat berdasarkan analisis belajar sambil bekerja,
8. Analisis Penggunaan metode yang sesuai

Scmidt dalam Mardikanto (2013:211) mengatakan agar pemilihan metode pemberdayaan masyarakat harus selalu mengacu kepada tujuan yang ingin dicapai oleh program pemberdayaan yang pada dasarnya menjadi dua, yaitu :

a) Menata pengalaman masa lampau yang telah dimilikinya dengan cara baru

b) Memberikan pengetahuan baru (pengetahuan, sikap dan keterampilan).

Sedangkan Mardikanto dalam Aprillia Theresia (2014:228) menguraikan ragam metode pemberdayaan masyarakat yang secara rinci dikemukakan dalam tabel sebagai berikut :

Tabel 8

Ragam Metode Pemberdayaan Masyarakat

\begin{tabular}{|c|l|l|l|}
\hline No & \multicolumn{1}{|c|}{ Kelompok Metode } & \multicolumn{1}{|c|}{ Ragam Metode } & \multicolumn{1}{c|}{ Keterangan } \\
\hline 1 & Tatap Muka & $\begin{array}{l}\text { Percakapan/dialog, } \\
\text { Pertemuan ceramah, diskusi, FGD, } \\
\text { pelatihan, } \\
\text { Pameran }\end{array}$ & $\begin{array}{l}\text { Individual } \\
\text { Kelompok } \\
\text { Masal }\end{array}$ \\
\hline 2 & Percakapan tak langsung & Telepon, TV, radio, teleconference & $\begin{array}{l}\text { Individual } \\
\text { Kelompok }\end{array}$ \\
\hline 3 & Demonstrasi & Demonstrasi cara, demonstrasi hasil. & Kelompok \\
\hline 4 & Barang cetakan & Foto, pamflet, brosur, baliho & $\begin{array}{l}\text { Media cetak } \\
\text { Rarat kabar, tabloid, } \\
\text { TV, VCD, DVD } \\
\text { Multi media }\end{array}$ \\
\hline 5 & Media masa & $\begin{array}{l}\text { Media } \\
\text { Terproyeksi }\end{array}$ \\
\hline 6 & Kampanye & \multicolumn{2}{|c|}{ Gabungan dari semua metode di atas } \\
\hline
\end{tabular}

Sumber : Mardikanto, 2014

Pemberdayaan masyarakat dengan prinsip penggunaan metode yang sesuai sudah dilaksanakan dengan baik, dengan demikian peneliti memberikan kesimpulan bahwa pemberdayaan masyarakat melalui Program Pembangunan Infrastruktur Perdesaan (PPIP) di Kecamatan Wanasalam Kabupaten Lebak sudah melaksanakan prinsip pemberdayaan masyarakat berdasarkan penggunaan metode pemberdayaan masyarakat yang sesuai. 9. Analisis Kepemimpinan,
Rogers dalam Mardikanto (2013:149) mengemukakan kualifikasi fasilitator pemberdayaan masyarakat dalam aspek kepemimpinan yaitu sebagai berikut :

1. Kemauan dan kemampuan untuk menjalin hubungan secara langsung dan tidak langsung dengan masyarakat penerima manfaatnya;

2. Kemauan dan kemampuan untuk menjadi perantara antara sumbersumber inovasi (lembaga penelitian, tokohmasyarakat)dengan 
pemerintah/lembaga pemberdayaan masyarakat dan masyarakat sasaran;

3. Kemauan dan kemampuan untuk menyesuaikan kegiatan-kegiatan yang dilakukan dengan kebutuhan-kebutuhan yangdapatdirasakanoleh pemerintah/lembagapemberdayaan masyarakat dan masyarakat sasaran.

Selanjutnya berdasarkan hasil datadata sekunder, peneliti kemukakan komponen program PPIP sebagai salah satu pengembangan masyarakat dalam aspek kepemimpinan yaitu program ini akan mendukung dan meningkatkan kemampuan masyarakat untuk memprioritaskan, merencanakan, melaksanakan, mengelola dan memantau pelaksanaan pembangunan infrastruktur dasar. Penguatan dilaksanakan melalui: (i) memposisikan masyarakat sebagai penentu/pengambil kebijakan dan pelaku utama pembangunan, (ii) mengutamakan nilai-nilai universal dan budaya serta kearifan lokal dalam pelaksanaan tahapan kegiatan, sesuai dengan karakteristik sosial, budaya dan geografis.

Berdasarkan uraian di atas, dapat disimpulkan bahwa pemberdayaan masyarakat melalui Program Pembangunan Infrastruktur Perdesaan (PPIP) di Kecamatan Wanasalam Kabupaten Lebak sudah melaksanakan prinsip pemberdayaan masyarakat berdasarkan analisis kepemimpinan.

\section{Analisis spesialis yang terlatih}

Lippit dan Rogers dalam Mardikanto (2013) bahwa fasilitator adalah pekerja atau pelaksana pemberdayaan masyarakat dan agen perubahan (agent change) yaitu seseorang yang atas nama pemerintah dan lembaga pemberdayaan masyarakat berkewajiban untuk mempengaruhi proses pengambilan keputusan yang dilakukan oleh (calon) penerima manfaat dalam mengadopsi inovasi. Karena itu fasilitator haruslah profesional dalam arti memiliki kualifikasi tertentu baik yang menyangkut kepribadian, pengetahuan, sikap dan keterampilan memfasilitasi pemberdayaan masyarakat.

\section{Tabel 9}

Evaluasi Kemampuan Organisasi Masyarakat Setempat dan Kader Desa

\begin{tabular}{|c|c|c|c|c|c|}
\hline URAIAN & 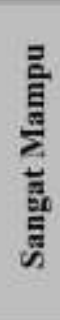 & 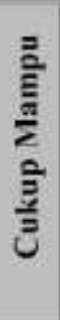 & 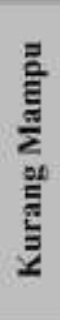 & 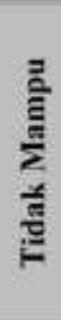 & 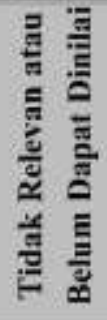 \\
\hline $\begin{array}{l}\text { Struktur dan Organisasi : } \\
\text { Pcranan dan Dukungan Kopala Desa }\end{array}$ & & $\sqrt{ }$ & & & \\
\hline Peran Ketua OMS & & $\sqrt{ }$ & & & \\
\hline Peranan Sckretaris, Bendahara dan Anggota OMS & & $\sqrt{ }$ & & & \\
\hline Kemampuan KD & & $\sqrt{ }$ & & & \\
\hline Pengaturan Biaya Umum & & $\sqrt{ }$ & & & \\
\hline$\frac{\text { Partissipasi Masvarakat : }}{\text { Pengambilan Keputusan selalu melalui Musyawarah }}$ & & $\sqrt{ }$ & & & \\
\hline Penggerakan Peran Perempuan & & $\sqrt{ }$ & & & \\
\hline Pemerataan Kesempatan Kerja & & $\sqrt{ }$ & & & \\
\hline Penciptaan / Perwujudan Keterbukaan atau Transparasi & & $\sqrt{ }$ & & & \\
\hline Pembangkitan Kontribusi Swadaya Masyarakat & & $\sqrt{ }$ & & & \\
\hline
\end{tabular}




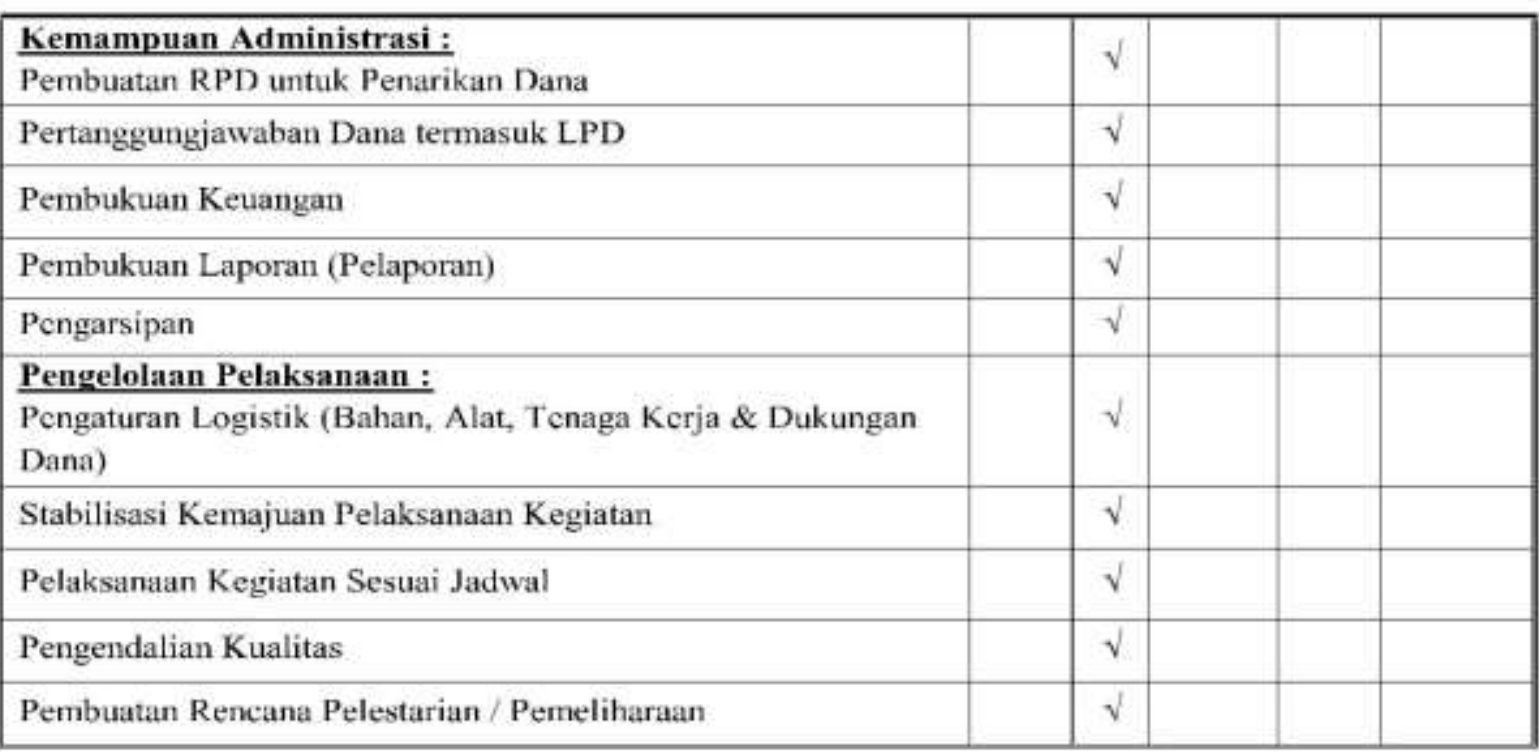

Dari uraian di atas, dapat disimpulkan pemberdayaan masyarakat melalui Program Pembangunan Infrastruktur Perdesaan (PPIP) di Kecamatan Wanasalam Kabupaten Lebak sudah melaksanakan prinsip pemberdayaan masyarakat berdasarkan analisis spesialis yang terlatih dengan baik.
11. Analisis Segenap keluarga,

Kegiatan PPIP sebagai salah satu program pemerintah yang fokus kepada pembangunan infrastruktur mengutamakan keluarga sebagai organisasi masyarakat yang terkecil, dan berikut adalah data sekunder berdasarkan komponen program, konsep dan dampak manfaat analisis segenap keluarga berikut ini :

Tabel 10

Matrik Analisis dampak masyarakat (keluarga)

\begin{tabular}{|c|c|c|}
\hline Komponen Program & Konsep (Panduan) & $\begin{array}{c}\text { Fakta Empiris Lapangan/Dampak } \\
\text { Analisis Segenap Keluarga }\end{array}$ \\
\hline $\begin{array}{l}\text { Penguatan kapasitas } \\
\text { perencanaan masyarakat }\end{array}$ & $\begin{array}{l}\text { Memposisikan masyarakat sebagai } \\
\text { penentu/pengambil kebijakan dan pelaku } \\
\text { utama pembangunan, (ii) mengutamakan } \\
\text { nilai-nilai universal dan bud aya serta } \\
\text { kearifan lokal dalam pelaksanaan tahapan } \\
\text { kegiatan, sesuai den gan karakteristik } \\
\text { sosbud dan geografis. }\end{array}$ & 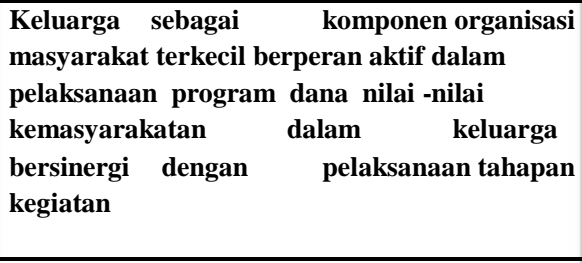 \\
\hline $\begin{array}{l}\text { Peningkatan layanan dan } \\
\text { penyediaan infra- struktur } \\
\text { Permukiman perdesaan } \\
\text { melalui Bantuan Langsung } \\
\text { Masyarakat }\end{array}$ & $\begin{array}{l}\text { Dana BLM disalurkan langsung ke desa } \\
\text { sasaran untuk mendukung pelaksanaan } \\
\text { rencana pembangunan }\end{array}$ & 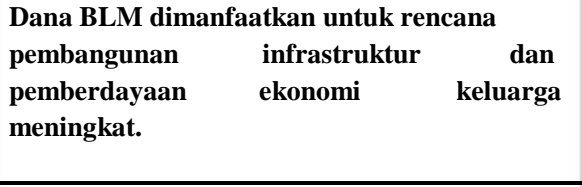 \\
\hline $\begin{array}{lr}\text { Peningkatan } & \text { kapasitas } \\
\text { Pelaksanaan } & \text { dan } \\
\text { Pengendalian } & \end{array}$ & $\begin{array}{l}\text { (i).Pendampingan dan fasilitasi oleh } \\
\text { konsultan manajemen, (ii). Peningkatan } \\
\text { pelaksanaan pengendalian dengan } \\
\text { menguatkan tugas dan fungsi setiap unsur } \\
\text { dalam struktur organisasi program, } \\
\text { (iii).Pengawasan dari seluruh lapisan } \\
\text { masyarakat melalui pe mantauan dan } \\
\text { evaluasi. }\end{array}$ & $\begin{array}{l}\text { Proses pendampingan dengan kontribusi } \\
\text { melalui pengawasan dan evaluasi } \\
\text { dilakukan oleh seluruh masyarakat } \\
\text { (keluarga) }\end{array}$ \\
\hline
\end{tabular}

Sumber : Hasil Analisis Peneliti, tahun 2015 
Dari uraian di atas, dapat disimpulkan pemberdayaan masyarakat melalui Program Pembangunan Infrastruktur Perdesaan (PPIP) di Kecamatan Wanasalam Kabupaten Lebak sudah melaksanakan prinsip pemberdayaan masyarakat berdasarkan analisis segenap keluarga.

\section{Kepuasan}

Salah satu tolok ukur dari keberhasilan sebuah proyek adalah tingkat kepuasan masyarakat terhadap proses dan hasil yang dapat dicapai selama program berlangsung.
Dalam evaluasi terhadap ketiga program ini, cara mengukur tingkat kepuasan masyarakat dilakukan melalui dua teknik yaitu wawancara terstruktur dan diskusi kelompok terarah (FGD). Aspek yang dilihat dari kepuasan masyarakat antara lain meliputi transparansi informasi program, pengetahuan masyarakat tentang program, ketersediaan informasi dan publikasi program, termasuk yang terkait dengan

mekanisme penanganan komplain masyarakat tentang program hingga kepada tingkat kepuasan masyarakat dan stakeholder/pemangku kepentingan terhadap pelaksanaan dan hasil program.

Tabel 11

Matriks Tingkat Kepuasan Masyarakat

\begin{tabular}{|c|c|c|}
\hline Variabel & Konsep (Panduan) & Fakta empiris lapangan \\
\hline Kinerja Teknis & $\begin{array}{l}\text { Seluruh kriteria } \text { teknis baik } \\
\text { secara kualitas maupun } \\
\text { kuantitas telah dipenuhi dan } \\
\text { diterapkan dengan baik }\end{array}$ & $\begin{array}{l}\text { Sebagian besar telah memenuhi } \\
\text { kriteria teknis dalam hal volume } \\
\text { pekerjaan bahkan terjadi penambahan } \\
\text { volume meski dengan anggaran yang } \\
\text { tetap. }\end{array}$ \\
\hline Kriteria Manajemen & $\begin{array}{lr}\text { Pengelolaan } & \text { program } \\
\text { memenuhi } & \text { kriteria } \\
\text { manajemen yang ditetapkan }\end{array}$ & $\begin{array}{l}\text { Pengelolaan sudah dilakukan } \\
\text { menurut prinisp dan pendekatan } \\
\text { pemberdayaan masyarakat }\end{array}$ \\
\hline Kriteria Keuangan & $\begin{array}{l}\text { Efektivitas dan } \\
\text { penggunaan } \\
\text { dengan baik }\end{array}$ & $\begin{array}{l}\text { Efektivitas dan efisiensi anggaran } \\
\text { telah dipenuhi }\end{array}$ \\
\hline Kriteria Organisasi & $\begin{array}{l}\text { Terjadinya } \\
\text { masyarakat }\end{array}$ & $\begin{array}{l}\text { Adanya partisipasi masyarakat dan } \\
\text { informasi (sosialisasi) proyek dari } \\
\text { tahap perencanaan, pelaksanaan dan } \\
\text { pengawasan. }\end{array}$ \\
\hline
\end{tabular}

Sumber : Hasil analisis peneliti, tahun 2015

Berdasarkan uraian di atas dapat dikemukakan bahwa tingkat kepuasan, pemberdayaan masyarakat telah mendorong agar masyarakat luas dapat mengetahui tentang program.Pengetahuan masyarakat terhadap program kelak dapat membantu partisipasi masyarakat untuk terlibat dalam pelaksanaan program hingga pengawasan dan pelestarian infrastruktur yang telah dibangun. Hal ini dilakukan melalui 2 bentuk kegiatan yakni sosialisasi program melalui pertemuan, publikasi atas

program.Disamping itu pengaduan masyarakat berkenaan dengan penyimpangan atau dampak negatif dari pelaksanaan program. Kesemua ini menunjukan bahwa program dirancang tidak semata mengukur kepuasan masyarakat dari sisi hasil fisik infrastruktur yang dibangun, melainkan juga dari aspek 
proses dari pelaksanaan pembangunan infrastruktur perdesaan.

Dari uraian di atas, dapat disimpulkan pemberdayaan masyarakat melalui Program Pembangunan Infrastruktur Perdesaan (PPIP) di Kecamatan Wanasalam Kabupaten Lebak sudah melaksanakan prinsip pemberdayaan masyarakat berdasarkan analisis kepuasan.

\section{E. KESIMPULAN DAN REKOMENDASI}

\section{Kesimpulan}

Berdasarkan hasil analisis dan pembahasan, maka dapat ditarik beberapa kesimpulan sebagai berikut ;

a) Pemberdayaan Masyarakat melalui Pembangunan Infrastruktur Perdesaan (PPIP) dalam meningkatkan kesejahteraan masyarakat Kecamatan Wanasalam Kabupaten Lebak sudah melaksanakan 10 (sepuluh) dari 12 (dua belas) prinsip-prinsip pemberdayaan masyarakat yang dikemukakan Dahatma dan Bhatnagar dalam Mardikanto (2013:106) yaitu analisis minat dan kebutuhan, analisis prinsip pengorganisasian masyarakat, analisis keragaman budaya lokal, analisis perubahan budaya, analisis belajar sambil bekerja, analisis penggunaan metode yang sesuai, analisis kepemimpinan, analisis spesialis yang terlatih, analisis segenap keluarga dan analisis kepuasan.

b) Pemberdayaan Masyarakat melalui Pembangunan Infrastruktur Perdesaan (PPIP) dalam meningkatkan kesejahteraan masyarakat Kecamatan Wanasalam Kabupaten Lebak belum melaksanakan 2 (dua) prinsip-prinsip pemberdayaan masyarakat dari 12 (dua belas) prinsip-prinsip pemberdayaan masyarakat yaitu prinsip pemberdayaan masyarakat berdasarkan analisis kerja sama partisipasi dan prinsip pemberdayaan masyarakat berdasarkan analisis demokrasi dalam penerapan ilmu, hal ini disebabkan karena :
1) Kurangnya pemahaman masyarakat tentang makna pemberdayaan masyarakat dan keberadaan Program Pembangunan Infrastruktur Pedesaan (PPIP);

2) Kurangnya sosialisasi yang diberikan oleh fasilitator masyarakat dan perangkat kelembagaan desa dalam memberikan informasi kegiatan dan

3) Kurangnya kesadaran masyarakat baik sebagai individu maupun anggota masyarakat menyangkut kondisi dan lingkungannya

4) Sebagian besar masyarakat tidak mempunyai kapasitas yang memadai untuk terlibat secara produktif dalam pengambilan keputusan

5) Adanya budaya kepatuhan warga masyarakat terhadap penguasa wilayah (tokoh formal maupun informal) yang mempengaruhi sikap masyarakat dalam kebijakan pengambilan keputusan.

\section{Rekomendasi}

Berdasarkan kesimpulan yang telah diuraikan di atas, disarankan halhal sebagai berikut :

1. Pemberdayaan masyarakat melalui Pembangunan Infrastruktur Perdesaan (PPIP) dalam meningkatkan kesejahteraan masyarakat Kecamatan Wanasalam Kabupaten Lebak yang sudah dilaksanakan berdasarkan 10 (sepuluh) prinsip-prinsip pemberdayaan masyarakat menurut Dahatma dan

Bhatnagar dalam Mardikanto (2013:106) perlu dipertahankan dan ditingkatkan dalam pelaksanaannya.

2. Pemberdayaan masyarakat melalui Pembangunan Infrastruktur Perdesaan (PPIP) dalam meningkatkan kesejahteraan masyarakat Kecamatan Wanasalam Kabupaten Lebak yang belum melaksanakan 2 (dua) prinsipprinsip pemberdayaan masyarakat, disarankan hal-hal sebagai berikut :

a. Fasilitator masyarakat perlu membangun komunikasi dan 
pemahaman serta komitmen kepada seluruh masyarakat tentang pentingnya program pembangunan infrastruktur dalam meningkatkan kesejahteraan masyarakat.

b. Pemerintah desa perlu mengoptimalkan kegiatan sosialisasi di tingkat desa mengenai kegiatankegiatan pemberdayaan masyarakat.

c. Melakukan proses penyadaran masyarakatbaik sebagai individu maupun anggota masyarakat tentang kondisi lingkungannya baik yang menyangkut lingkungan fisik, sosial budaya dan ekonomi termasuk menunjukkan pentingnya perubahan untuk memperbaiki keadaannya.

d. Memberikan kesempatan pendidikan non formal kepada masyarakat sebagai upaya penguatan modal sosial dengan pelibatan masyarakat dalam berbagai kegiatan sekaligus mengurangi peranan fasilitator dalam pengambilan keputusan dan meningkatkan intensitas kegiatan kepada masyarakat.

e. Fasilitator masyarakat harus mendorong masyarakat untuk berani berpartisipasi dalam mengemukakan pendapat, ide dan gagasan dalam proses pengambilan keputusan dengan tetap memperhatikan dan mempertimbangkan karakteristik budaya, nilai-nilai sosial dan peraturan dalam masyarakat.

\section{F. DAFTAR PUSTAKA}

Girsang LJ. 2011. Faktor yang mempengaruhi partisipasi masyarakat dalam kegiatan perbaikan prasarana jalan (Kasus: Program Nasional Pemberdayaan Masyarakat (PNPM) Mandiri Perdesaan di Desa Megamendung, Bogor)

Hasan, Iqbal, Pokok-pokok Materi Metodologi Penelitian dan Aplikasinya. Jakarta, Ghalia Indonesia
Kartasasmita, Ginanjar, 1997, Administrasi Pembangunan. Jakarta, LP3ES

Mardikanto T dan Soebiato P, 2013, Pemberdayaan Masyarakat. Bandung, Alfabeta

Michael, Todaro, 1977, Pembangunan ekonomi di dunia Ketiga, Jakarta Erlangga,

Siagian, Sondang P, 1994, Administrasi Pembangunan, Jakarta, Gunung Agung

Sumaryadi, I Nyoman, 2005, Perencanaan Pembangunan Daerah Otonom dan Pemberdayaan Masyarakat, Jakarta: Penerbit Citra Utama

Sumaryadi, I Nyoman, 2005, Perencanaan Pembangunan Daerah Otonom dan Pemberdayaan Masyarakat, Jakarta: Penerbit Citra Utama

Sumodiningrat G. 1999. Pemberdayaan masyarakat dan jaringan pengaman sosial. Jakarta [ID]: Gramedia Pustaka Utama.

Theresia, Aprillia, at al, 214, Pembangunan Berbasis Masyarakat Bandung, Alfabeta

W.J.S. Poerwadarimta, 1996, Pengertian Kesejahteraan Manusia, Bandung, Mizan

Buku Pedoman Pelaksanaan Program Pembangunan Infrastruktur Perdesaan (PPIP), Direktorat Jendral Cipta Karya Kementrian Pekerjaan Umum, 2014

Undang-Undang No 23 Tahun 2014 tentang Pemerintahan Daerah

Undang-undang No. 25 Tahun 2004 tentang Sistem perencanaan pembangunan Nasional.

Undang-undang No. 32 Tahun 2004 Tentang Otonomi Daerah.

Undang-undang Nomor 11 Tahun 2009 tentang ketentuan-ketentuan pokok kesejahteraan sosial 


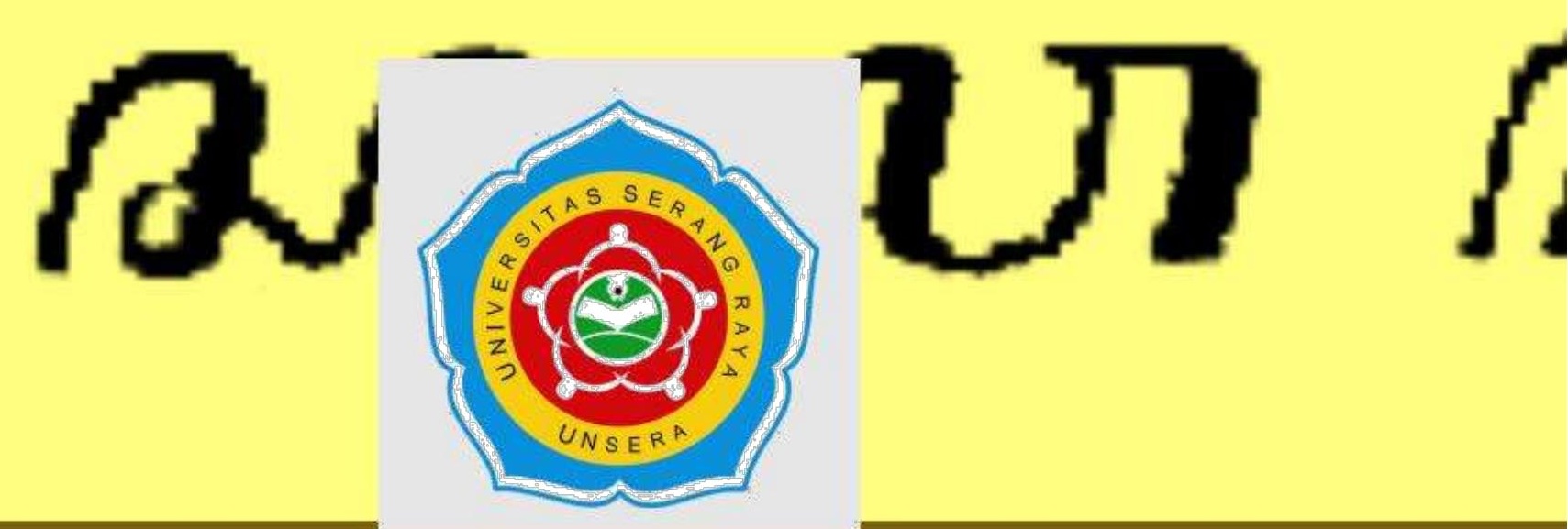

Program Studi Ilmu Administrasi Negara Pusat Studi Sosial dan Pengabdian Masyarakat (PS2PM) FISIP UNSERA Fakultas Ilmu Sosial dan Ilmu Politik Universitas Serang Raya

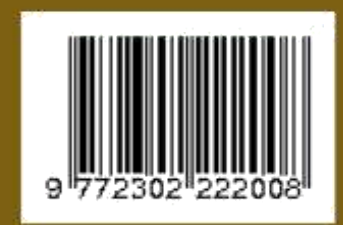

